\title{
Islam in China--A History of European and American Scholarship (The $21^{\text {th }}$ Century)
}

\author{
Alimu Tuoheti \\ Frontier Research Institute for Interdisciplinary Sciences, Tohoku University, Sendai, Japan \\ Email address: \\ tuoheti.alimu@orinst.ox.ac.uk

\section{To cite this article:} \\ Alimu Tuoheti. Islam in China--A History of European and American Scholarship (The $21^{\text {th }}$ Century). History Research. \\ Vol. 9, No. 1, 2021, pp. 39-48 doi: 10.11648/j.history.20210901.15
}

Received: December 28, 2020; Accepted: February 8, 2021; Published: February 20, 2021

\begin{abstract}
The studies of Chinese Islam by worldwide academic society are consisted of two schools, "western" and "Japanese". I will focus my research "The studies of Chinese Islam by European and American Academic Society". In this paper, mainly related to the research situation since the 21 the century. Since the 2000's, the study of Chinese Islam and Muslim in the West has become more and more prosperous, however, there is little understanding of these works in the World research community. we should also see that Chinese Islamic studies are still in a relatively marginal position in western academic circles. Chinese Islam and culture are a part of the world's Islam and culture. on the other hand, they are part of Chinese culture. Chinese Muslims are also dividing into Uyghur, Kazak of Turkic language family, and Hui of Chinese language family. It is of great significance to understand Chinese Islam. According to the perspective of academic history, there have been some research results in this area. In this paper, mainly from "Research opportunities under the background", “About 'Muslim Confucian' studies", "Academic works based on field work", "Research in the political field", "Research on religion, ethnicity, and Culture" topics for research. The carding and analysis of these research results is conductive to the development of the world's research on Chinese Islam.
\end{abstract}

Keywords: European, American, Academic Studies, Mainland China, The $21^{\text {th }}$ Century

\section{Introduction: Research Opportunities Under the Background}

This pertains to the need to recognize the difference between civilizations, emphasize the dialog between religions, and advocate promoting mutual understanding of human society based on seeking common ground while reserving differences. Therefore, the dialog between Islamic and other civilizations - and between Islam and other religions - has surged in recent years. Indeed, regardless of the clash of civilizations or the religious dialog, they are all rooted in the basic background that the phenomenon of religious pluralism will flourish in the $21^{\text {st }}$ century. Therefore, there is no denying that one of the problems closely related to the two is the study of religious pluralism.

The following discusses the research background of civilizational conflict and dialog. On the Clash of Civilizations, Samuel P. Huntington (1927-2008), a famous contemporary American political theorist, published this book and other articles in 1996, and later compiled relevant theories into the far-reaching The Clash of Civilizations and the Remaking of World Order. [1] The book was translated into 39 languages, which aroused increasingly more repercussions in the world. However, the 9/11 incident forced people to return to Huntington's concepts, as follows. First, the root of the future world's international conflicts will be mainly cultural rather than ideological and economic. The main conflicts of global politics will be between countries and groups of different civilizations. The conflicts of civilizations will dominate global politics. The (geopolitical) fracture zone among civilizations will become the future front. Second, the clash of civilizations is the greatest threat to world peace in the future. The world order based on civilizations is the most reliable guarantee to avoid world war. Therefore, it is very important to cross boundaries among different civilizations, and it is also very important to respect and recognize each other's boundaries among different civilizations. Third, for the first time in history, there have been multipolar and multi-civilized global 
politics; generally speaking, countries with different cultures are most likely to be alienated and indifferent to each other, or highly hostile to each other, while civilizations are more likely to have competitive coexistence, that is, the Cold War and cold peace, ethnic conflicts will prevail. Fourth, the conflicts between cultures of civilizations are mainly the conflicts among the seven civilizations in the world, and Islamic civilization and Confucianism may jointly threaten or challenge Western civilization.

Huntington's point of view is even more surprising and unacceptable to many people, not just international experts. This specifically involves the notion that the main source of future instability and the possibility of war comes from the revival of Islam and the rise of East Asian society, especially China; and the relationship between the West and these challenging civilizations may be extremely difficult, among which the relationship between the United States and China may be the most dangerous.

Tu Weiming criticizes Huntington's perspective and believes that the "clash of civilizations" is not the mainstream of the world's cultural development. He asserts that Huntington's understanding of culture is very one-sided, standing on a narrow political standpoint, reflecting the unhealthy mentality of some people in American society after the end of the Cold War. Although the theory of "Clash of Civilizations" has had considerable influence, and this kind of thought is still developing, its influence will be increasingly weaker in the future, because its rationale is questionable. Now, facing the $21^{\text {st }}$ century, there should be more communication and exchange between different ethnic groups and different civilization systems to form a global "dialog of civilizations" between various products of Eastern and Western civilizations. These encompass Hinduism, Islamism, and Jainism in East Asia and South Asia, Confucianism, Taoism and Mahayana Buddhism in China, Judaism, and Christianity. Under the impact of academic research upsurge in this field such as "Clash of Civilizations" and "Dialog of Civilizations," the research on the dialog between Chinese Islamic civilization and other civilizations has also achieved certain results. Tu Weiming, a professor at Harvard University, has worked closely with Nanjing University, Yunnan University, Ningxia Academy of Social Sciences and other institutions to carry out a series of research activities and published many achievements. Many academic conferences comprising different levels of dialog have been held in China, including the International Symposium on the Dialog of Civilizations with the focus on the dialog between Hui and Confucianism, held in Yinchuan, Ningxia, Kunming, Yunnan and the International Symposium on "Life and Death: The dialog between Hui and Buddhism" held in Beijing. Meanwhlie, some achievements have been made in the study of the interaction between Islamic and Chinese civilizations, especially between Islam and Chinese Confucianism. This directly relates to the study of "Chinese Islamic studies":

Islamic teaching can be defined as the academic attribute of religious teaching in Islam. In a broad sense, Islamic teaching can include the fields of classics (classics, sermons, etc.), pedagogy, dogmatism, sectarianism, etc. Dogmatism is a traditional Islamic discipline formed in the process of Muslims' rational and speculative interpretation of faith. Islamic dogmatism has always been given great importance by Chinese Muslims, and it is the main sphere of scripture education and Chinese translation since the Ming and Qing dynasties. Islamic law is also an important part of Islamic teaching. The study of Islamic law in contemporary China has formed a disciplinary system with the main characteristics of focusing on Chinese characteristics and realistic dimensions. At present, it is facing the methodological transformation of how to use the study of Islamic law to become more advanced modern knowledge. Influenced by traditional Islamic jurists and modern Western Islamic jurists, there are two academic traditions in this field, namely "traditionalists" and "academics."

The whole Islamic society in China has evolved from Muslim immigrants from Arabia, Persia, Turkic regions, and Central Asia. During the Ming and Qing dynasties, the Chinese Islamic community experienced a long period of Sinicization and localization, and its cultural thoughts and Chinese Islamic consciousness were in a critical period of development. During this period, some intellectuals emerged who were proficient in Islamic classics and Confucianism, possessing a dual cultural temperament of the two faiths. These intellectuals, based on Islamic philosophy and under the overall influence of Chinese Confucianism, especially Neo-Confucianism in the Song and Ming dynasties, have created a new theoretical system in Chinese Islamic studies.

The establishment of Chinese Islamic studies is not only a contribution to Chinese Islam but also Chinese civilization more broadly. In a special sense, it also proves the close relationship between Confucianism and Islam. Tu Weiming representatives include Wang Daiyu, Zhang Zhong, Wu Zunqi, Ma Zhu, Liu Zhi, Ma Dexin, and Ma Lianyuan. They carried out the enlightenment movement with great historical significance in the history of Chinese Islamic thought. Wang Daiyu and Liu Zhi, who have made great contributions to the creation of the Chinese Islamic system, are Islamic scholars. Wang Daiyu is the most important pioneer of this academic system. He creatively explored the purpose, task, content, and road for the ideological enlightenment. Liu Zhi's thought always followed the road that Wang Daiyu had opened to combine the Islamic doctrine with the Chinese Confucian doctrine, and he made it standardized, refined, and more speculative. On the basis of Islam and Islamic theology, philosophy, ethics, and politics, Wang Daiyu and Liu Zhi's thoughts were created by critically absorbing Confucianism, especially Neo-Confucianism in the Song and Ming dynasties.

\section{About "Muslim Confucian" Studies}

In recent years, some foreign scholars have begun to study the works of representatives of the Chinese Muslim "Han Kitabu" movement. As a result of the intersection of Chinese 
traditional culture and Islamic culture, Chinese Islamic literature and records have attracted increasingly more attention. More scholars have proposed that, because of the contribution of Chinese Islamic literature to diversified Islamic thought, it should enjoy the same important status and more attention as the content in other languages has received. Key proponents include the American scholar Sachiko Murata and Willam C. Chittick.

\subsection{Sachiko Murata and William C. Chittick and Their Research}

Sachiko Murata received a bachelor's degree from Chiba University in Japan, and later studied at Tehran University in Iran. She was the first woman to study Islamic law and has a doctorate in Persian Literature. Murata now professor at Stony Brook university and where she researches and teaches Islam, Confucianism, Taoism, and Buddhism.

William Chittick received his bachelor's from Worcester college in Ohio. And then his doctorate in Persian Literature from Tehran University under the guidance of Sayed Hossein Nasr. He taught comparative religion at a university in Tehran and left Iran before the revolution. Now, he is a professor Stony Brook university, mainly studies Islam and Sufi.

The following was jointly published by Sachiko Murata, Willam C. Chittick, and Tu Weiming: "Chinese Gleams of Sufi Light: Wang Tai-Yu's Great Learning of the Pure and Real and Liu Chih's Displaying the Concealment of the Real Realm" [2] and "The Sage Learning of Liu Zhi: Islamic Thought in Confucian Terms" [3]

(1) Chinese Gleams of Sufi Light:

The contents of this book are divided into: The Works of Wang Tai-yu (The True Answer, The Real Commentary on the True Teaching, Adam and Eve: From Chapter Two of the Real Commentary, The Real Solicitude); Wang Tai-yu's Great Learning (The Chinese Background, The Islamic Concepts, The Text); The Great Learning of the Pure and Real (Synopsis: Comprehensive Statement, The Real One, The Numerical One, The Embodied One, General Discussion); Liu Chih's Translation of Lawa'ih (The Oneness of Existence, Liu Chih's Appropriation of Lawa'ih, The Translations); Gleams; and Displaying the Concealment of the Real Realm.[2]

Chinese Gleams of Sufi Light investigates, for the first time in a Western language, how Chinese Muslim scholars adapted the Chinese tradition to their own needs during the seventeenth and eighteenth centuries. The book surveys the 1400-year history of Islam in China and explores why the four books translated from Islamic languages into Chinese before the twentieth century were all Persian Sufi texts. The author also carefully considers the two most important Muslim authors of books in the Chinese language-Wang Tai-yu, and Liu Chih. Murata shows how they assimilated Confucian social teachings and Neo-Confucian metaphysics, as well as Buddhism and Taoism, into Islamic thought. She presents full translations of Wang's Great Learning of the Pure and Real - a text on the principles of Islam and Liu
Chih's Displaying the Concealment of the Real Realm, which in turn is a translation from the Persian Lawa 'ih,' a famous Sufi text by Jami. A new translation of Jami's Lawa'ih' from the Persian by William C. Chittick is juxtaposed with Liu Chih's work, revealing the latter's techniques in adapting the text to Chinese language and thought.

(2) "The Sage Learning of Liu Zhi"

The introduction of the book is divided into discussing Liu Zhi and the Han Kitab (Liu Zhi, The Persian and Arabic Sources, The Arabic Translation of the Root Classic); The Islamic Background (The Quest for Realization, Fields of Understanding, Wisdom, The Real, The World Map, Sovereignty and Kingdom, Origin and Return, Microcosm and Macrocosm, Names and Attributes, Spiritual Anthropology, Actualization of the Divine Form, The Divine Presences); Liu Zhi's Adaptations of Islamic Thought (Nature and Principle, Spirit 54, Xingli Li and Ruh, Xing and Tabi'a, Mandate, Former Heaven and Latter Heaven, Complete Substance and Great Function, Prophethood and Sagehood, One Body with Heaven and Earth); and The Structure and Argument of Tianfang Xingli. Islamic scholars Seyyed Hossein Nasr wrote the foreword: "The first product of this collaboration, the remarkable work Chinese Gleams of Sufi Light, contains the translation of two Chinese texts in English, their analysis, a new English translation of "AbdalRahman Jami's Lawa'ih" (one of the texts studied in its Chinese translation) from the Persian by Chittick, and indepth comparisons. The work became a landmark study in comparative philosophy, mysticism, and religion as far as the Islamic and Chinese traditions are concerned."

During these efforts, the group became aware that they were dealing only with the tip of the iceberg and many other important texts of the Han Kitab deserved to be studied indepth. Accordingly, they turned their attention to the more extensive and highly influential work of Liu Zhi, the seventeenth- century master of this school: Tian-fang xingli (Nature and Principle in Islam). This was first published in 1704 and represented the result of several years of effort to study and translate this work and to provide detailed commentaries and references to Islamic sources. Among the most interesting features of this treatise is the explanation of metaphysical and cosmological ideas through the use of numerous diagrams. Perhaps the author's extensive use of diagrams can nevertheless remind us of diagrams in the philosophical and metaphysical works of such Islamic authors as Ikhwan al-Safa, Ibn "Arabi, and Sayyid Haydar Amuli." [4]

"Epilogue" is written by Tu Weiming: "I would like to conclude with four observations: 1. Liu Zhi's accomplishment is widely acknowledged by Chinese Muslim theorists and practitioners as one of the most sophisticated, systematic, original, and creative articulations of Islamic philosophy in the golden age of Islam in China. He will be recognized as a profound resource for Chinese Islamic intellectual self-definition. 2. Islamic Nature and Principle is a major contribution to Confucian thought in the late Ming and early Qing dynasties as well as to Muslim-Han dialog. It 
will broaden the philosophical horizons of Confucian thinkers and compel Chinese intellectual historians to reexamine their underlying assumptions about the Three Teachings. 3. It has enriched and enlarged the Confucian discourse comparable to and in several areas more significantly that the great work of the Jesuits, notably the endeavor of Matteo Ricci. 4. It will undoubtedly stimulate new research and interpretation in the comparative study of religion and philosophy as well as in Chinese and Islamic studies." [5]

This is compared with the original work of Jamie, a mystical Sufi poet in Persia. His research is based on hard archaeological literature mining and is closely related to the dialog between the Hui and Confucianism advocated by Tu Weiming. In fact, in one regard, the book reflects the author's hold of the research tradition of Japanese scholars on Chinese Sufism literature, such as his research on Sufi and Taoism; simultaneously, it reflects the recent Western academic circles, mainly initiated by the new Confucians, concerning and interested in the translation of Chinese Islamic works during the Ming and Qing dynasties. This remains a research area with great potential.

In 2012, Sachiko Murata and Willam C. Chittick were visiting scholars at Peking University, specializing in the study of Islam in China. At that time, I conducted postdoctoral research at Peking University and I worked with them to hold an academic seminar: "The Contemporary Value of the Worldview of Huiru and Islamic studies in China." We invited eminent academics from Europe, America, and China, aiming to improve the research in the field. Murata and Chittick presented a speech at the meeting: "Why Study the Worldview of the Huiru? (1) and (2)." Their main point of view is: "Since that time, we have had a good deal of interaction with Chinese scholars and students of Islam. It is clear to us that many Chinese are not able to see the teachings of the Huiru as continuous with those of mainstream Islam. The major reason for this seems to be the break in the transmission of Huiru thought brought about by events in the twentieth century. Chinese Muslims have had to re- learn their religious tradition because of the disappearance of the educational systems that sustained it. Mostly they rely on outside sources, often written by Western historians.

"I will draw from the most outstanding of the Chinese Muslim philosophers, Liu Zhi. His Tianfang Xingli sets down the Huiru worldview in a systematic and meticulous manner. The book allows us to see the basic principles briefly and succinctly, and it also explains the detailed implications of these principles. The brilliant manner in which Liu Zhi expressed his philosophical vision seems to be unparalleled among Huiru authors. I doubt if any text in any Islamic language can rival Tianfang Xingli in portraying the various dimensions of Islamic thought and practice in such a systematic, succinct, and all-comprehensive manner.

"What then is the Huiru worldview? In brief, it is identical to the worldview discussed by countless books written in Arabic, Persian, and other languages by great Muslim teachers, people who were known as theologians, Sufis, or philosophers, and sometimes as all three. In theoretical terms, this worldview is expressed most briefly as the three principles of Islamic thought: unity, prophecy, and return." [6]

\subsection{Other Scholars and Their Research}

(1) Additionally salient in this field are Zvi Ben-Dor Benite's research outputs: The Dao of Muhammad: A Cultural History of Muslims in Late Imperial China.[7] The contents of the book are divided into The Islamic Educational Network; Self-Perception and Identity among the Scholarly Constituency; The Han Kitab Authors and the Chinese Islamic School; Muhammad and His Dao: and Knowledge and Identity in the Han Kitab.

(2) James D. Frankel, Rectifying God's Name: Liu Zhi's Confucian Translation of Monotheism and Islamic Law:[8]

The contents of the book are divided into: The World of Liu Zhi; Chinese Muslim Tradition and Liu Zhi's Legacy; Liu Zhi's Concepts and Terminology; Ritual as an Expression of Chinese-Islamic Simul Taneity; The Spirit of Ritual and the Letter of the Law; and ALLA's Chinese name.

(3) The third chapter introduces Jonathan N. Lipman's research achievements in the field of thought. He recently synthesized and edited a book on the research results of other scholars in this field: Islamic Thought in China: Sino-Muslim Intellectual Evolution from the 17th to 21st Century [9]

Lipman wrote the following two parts:

Jonathan Lipman, "Editor's Introduction: Four Centuries of Islamic Thought in Chinese" "Muslims have lived in the Chinese culture area since the seventh or eighth centurythe mid-Tang dynasty-and have acculturated, as all immigrants do, to live comfortably in what began as an alien environment. Over a millennium, through ordinary social processes, including intermarriage with local women, they ceased being utterly foreign and became local but different, Sinophobe but not entirely Chinese."

Jonathan Lipman, "A Proper Place for God: Ma Zhu's Chinese-Islamic Cosmogenesis (pp. 15-33) "In the Ming period (1368-1644), Chinese Muslim writers began to explain their ancestral religion of Islam in the language and conceptual schema of their contemporary Chinese culture. That is, they participated bully in two literate, selfconfident, and, at least potentially, exclusive cultures, so they had to produce a textual justification that allowed them to be legitimate insiders in both. This will be a constant theme in this book, for the same impulse has continued to motivate Chinese Muslim intellectuals to think and write for the past 400 years."

Other articles in the income book include:

James D. Frankel, "The Great Integrator of Chinese Islamic Thought" (pp. 34-54)

Roberta Tontini, "Tianfang Sanzijing: Exchanges and Changes in China's Reception of Islamic Law" (pp. 55-80) Kristian Petersen, "The Multiple Meanings of Pilgrimage in Sino-Islamic Thought" (pp. 81-104)

Wlodzimierz Cieciura, "Ethnicity or Religion? Republican-Era Chinese Debates on Islam and Muslims" 
Yufeng Mao, "Selective Learning from the Middle East: The Case of Sino-Muslim Students at al -Azhar University" (pp. 147-170)

Masumi Matsumoto, "Secularization and Modernization of Islam in China: Educational Reform, Japanese Occupation and the Disappearance of Persian Learning" (pp. 171-196) Leila Cherif-Chebbi, "Between 'Abd al-Wahhab and Liu Zhi: Chinese Muslim Intellectuals at the Turn of the Twenty-first Century" (pp. 197-232)

(4) Tontoni, Roberta. Muslim Sanzijing: Shifts and Continuities in the Definition of Islam in China: [10]

The contents of the book are divided into: Tianfang Dianli: Norms and Rites of Islam in Imperial China; Tianfang Sanzijing: A Regional Theory on Islamic Law; Islamic Law in the Aftermath of the Anti-Qing Rebellions; Rethinking Liu Zhi's Legacy in Postimperial China; Islam's Filiative Transmission to Modernity; and Conclusion: The Great Learning of Islam in China.

In Muslim Sanzijing, Roberta Tontini traces the history of Islam and Islamic law in China through a rigorous analysis of popular Chinese Islamic primers from the 18 th to the $21 \mathrm{st}$ century.

(5) Shen, Yiming, Chinese Islamic text studies in the seventeenth and eighteenth centuries: a case study of Chinese translations of Jami's Persian Sufi prose. Ph.D. Thesis. SOAS, University of London.

\section{Academic Works Based on Field Work}

\subsection{Maris Boyd Gillette and Her Studies}

Dru C. Gladney has made many research achievements in fieldwork. After 2000, his students also inherited his research methods and published some research results, e.g., American scholar Maris Boyd Gillette.

Gillette published her research on Xi'an Huifang in 2000: Between Mecca and Beijing: Modernization and Consumption Among Urban Chinese Muslims. [11] Gillette completed her research in Xi'an, which involved 18 months of fieldwork, collecting extensive first-hand information.

A review on Gillette's book is as follows: "Based on fresh and solid ethnographic materials, the study demonstrates that even though the majority of Xi'an Hui desire and embrace the modernization paradigm promoted by the Chinese partystate, the specific vision of modernization and meaning of being modern differ greatly from the officially sanctioned ideology. In other words, this group of people may have adopted the goals and language of modernization and consumerism offered by the state, but they frequently draw inspiration and social imagination from a quite different source "Arabized Islamic modernity" as their index of civilization and an alternative vision of modernization. This tendency is most clearly manifest in the Arabization of the architectural style of recently built mosques in the community. Because this alternative way of defining and pursuing modernization is located outside the state's purview and direct control, it often invokes anxieties and creates tensions between this Muslim community and local government (largely dominated by Han Chinese). The author shows nicely both the continued salience of state power and its limits in an increasingly marketized consumer society. On the one hand, the Chinese party-state can instill a metanarrative of progress among its citizens and presents itself as the sole legitimate director of state-guided modernization. On the other hand, there have emerged several unintended consequences in everyday practices of modernization that go beyond state control. With increased wealth, consumption power, and access to trans-local and transnational flows of material goods, Xi'an Hui, as well as other Chinese citizens, have gained more personal freedom and space in their consumption choices and private life. Yet, often caught between the practical consideration of economic gain and the concern for social control, local government's response to these new consumption practices is largely ambivalent." [12]

This book is another Western scholarly anthropological work of studying the Muslim community in China after Dru C. Gladney’s "Chinese Muslims." Differing from Gladney, Gillette, from the perspective of "modernization and consumption," uses economic anthropology, sociology, and the theory of consumerism culture to study the Muslim community of China's hui nationality in a city. Following Gladney, Gillette has again expanded the research field of Hui nationality. However, the author's interpretation of Xi'an Hui's consumption and modernization hides the Western "modernity" complex and values. [13]

\subsection{Maria Jaschok and Her Studies}

Regarding relevant fieldwork, another scholar to introduced is Professor Maria Jaschok of Oxford University.

Jaschok's research interest is in the areas of religion, gender and agency; gendered constructions of memory; feminist ethnographic practice; and marginality and identity in contemporary China. She is involved in ongoing collaborative research projects in central China, addressing issues of religious and secular identity, and implications of growing female membership of both officially sanctioned religions and local cults for women's participation in, and contribution to, civil society. Female Chinese Muslims were her research object.

In 2000, Jaschok cooperated with Chinese scholars to publish the research output: The History of Women's Mosques in Chinese Islam: A Mosque of Their Own.[14] The Chinese version of the book was also published in 2002 by Sanlian Bookstore as a kind of Sanlian-Harvard Yanjing academic series.

The contents of the book are divided into: Muslim Women in Chinese Islam; Islamic Faith Innovation Bida; The Beginnings and History of a Female Religious Culture; Growth and Expansion of Women's Mosques and Schools; Women's Mosques Nu Ahong and their Religious; The Road to Allah's Commandments Conflicts of Loyalty; Women's Mosques; Re-engendering the Past; Xiuti From Head to Toe, Shaming and Concealing the Body; Mediating Spiritual Faith; Community Choices; Living in God's Shadow; Nusi in 
the Republican Era 1912-1949; and Unpublished Documentation on Central Chinas. [14]

Shuijingjun asserts that the writing of the book embodies a method of dialog and its results. Dr. Laura Newby of Oxford University commented: "Perhaps the greatest contribution of this book is to add the voice of Chinese Muslim women to the theoretical discussion of international feminist scholars." However, for the Hui research community in China, this book should introduce feminism into Hui research.

Jaschok also has the following research outputs:

The History of Women's Mosques in Chinese Islam, coauthored with Shui JJ (Curzon, 2000)

The History of Women's Mosques in Chinese Islam: A Mosque of Their Own, The China Journal, (2002)

"Gender, Religion, and Little Traditions: Chinese Muslim Women Singing Minguo" in Women in China. The Republican Era in Historical Perspective, M Leutner, and N. Spakowsiki, eds. (LITT Verlag Berlin, 2005)

"Women's Mosques Education, Female ignorance and Chants to Save Souls; Chinese Hui Muslim Women Remembering Jingge, Remembering History" in Studies in Adult and Community Education, 52(The Japan Society for the Study of Adult and Community Education, Tokyo, 2008)

"Education, Gender and Islam in China: The Place of Religious Education in Challenging and Sustaining 'undisputed traditions' among Chinese Muslim women," co-authored with. M. V. Chan (International Journal of Educational Development, 2009)

"Women, Space, and Religion in China-Islamic Mosques \& Daoist Temples, Catholic Convents \& Chinese Virgins," co-authored with Shui JJ (Routledge, NY, 2011)

"Chinese Hui Muslim Pilgrims-Back Home from Mecca: Negotiating Identity and Gender, Status

and Afterlife," in The Changing World Religion Map: Sacred Places, Identities, Practices, and Politics, edited by Stanley D. Brunn. (Springer, 2015)

"Education, Gender, and Islam in China: The Place of Religious Education in Challenging and Sustaining "undisputed traditions" among Chinese Muslim Women," in Waling the Tightrope: Asian Muslim Women and their Lived Realities, edited by-Huma Ahmed-Ghosh. (New York: State University of New York Press, 2015)

(With Rachel Harris): "Introduction: Sounding Islam in China," in Performing Islam (3)1\&2:11-21(2014 Intellect Ltd. Doi:10.1386/pi.3102.11-2.2015)

"Sound and Silence in Chinese Women's MosquesIdentity, Faith and Equality," in Performing Islam (3)1\&2:59-82. (2014 Intellect Ltf. doi:10.1386/pi.31-2.112.11.2015)

Furthermore, S. Frederick Starr edited the following books: Xinjiang: China's Muslim Borderland.[15] The contents of the book are divided into: Historical Background; Political and Cultural History of the Xinjiang Region throughout the late nineteenth century; Political History and Strategies of Control 1884-1978; Chinese Policy Today; The Chinese Program of Development and Control 1978-2001;
The Great Wall of Steel Military and Strategy in Xinjiang; The Economy of Xinjiang; Education and Social Mobility among Minority Populations in Xinjiang; A Land of Borderlands Implications of Xinjiang's Transborder Interactions; Costs of Control and Development; The Demography of Xinjiang; The Ecology of Xinjiang A Focus on Water; Public Health and Social Pathologies in Xinjiang; The Indigenous Response; Acculturation and Resistance Xinjiang Identities in Flux; Islam in Xinjiang; Contested Histories; and Responses to Chinese Rule Patterns of Cooperation and Opposition.

This comprehensive survey of contemporary Xinjiang is the result of a major collaborative research project begun in 1998. The authors have combined their fieldwork experience, linguistic skills, and disciplinary expertise to assemble the first multifaceted introduction to Xinjiang. The volume surveys the region's geography; it's history of military and political subjugation to China; economic, social, and commercial conditions; demography, public health, and ecology; and patterns of adaptation, resistance, opposition, and evolving identities.

In terms of field research, another prominent contributor is French scholar Lisabeth Alls, publishing Musumans de Chine: Une Anthropologie des Hui du Henan. [16]

\section{Research in the Political Field}

Islam has a deep connection with its adherents' lives, especially in the contemporary social and political life in China's Xinjiang, Gansu, Ningxia and other Islamic areas; the relationship between Islam and social politics is closer. Contemporary scholars even call it "the Islam of politics," "the Islamization of politics," and "the politicization of Islam," etc. The evolution of modern Islamic politics into the 20th century has formed three major schools: nationalism, modernism, fundamentalism, and the evolution of these schools in the 21 st world is more obvious. Nationalists regard modern nationalist country and social outlook as the political cornerstone, Islam as ideological belief, and separation of politics and religion as basic state policy. The modernists consider the early Islamic political tradition as an example and advocate the political principles of nationality, freedom, and equality. Fundamentalists believe that the invasion and expansion of Western powers has coincided with the decline of Muslim national politics in modern times; only by reviving Islamic tradition, including its political principles, ideas, and ethical norms, can Muslim countries enjoy peace and stability.

The study of Islam and Muslims in China by foreign scholars involves different ethnic groups, and different economic and political conditions. It encompasses not only the research field of religious teaching but also the academic frontier characteristic of interdisciplinary research. At present, many events in China's Islamic region are related to this religion, but not all events are Islamic, nor religious in nature. From a deep perspective, it cannot be perceived that these great theories are directly related to China's politics and 
utilization. Ten ethnic groups in China believe in Islam, and their Islamic religious problems inevitably affect the country's political and social conditions, among other fields. The international Islamic unrest also naturally affects the Chinese Muslim society.

From the perspective of academic research, these situations have aroused the attention and research of scholars both at home and abroad on the Islamic political and social issues in China. Recently, problems related to the political life of Islam in China have materialized, as well as the research results of Islamic social thoughts and social movements.

After entering the 21 st century, one of the characteristics in the political field is: China's One Belt, One Road. The Silk Road Economic Belt and the 21st Century Maritime Silk Road Initiative and Cooperation Initiative have been frequently studied recently. Islam is an important factor that cannot be dismissed concerning the One Belt, One Road construction. We should fully understand and consider the religion's influence, and then we can give full play to its advantages, prevent risks, promote regional common development, and maintain social prosperity and stability. The One Belt, One Road construction is China's major contemporary development strategy. Meanwhile, the initiative is the core area of the Silk Road Economic Belt construction, with its unique traffic, economic, and cultural advantages. Islam also remains an important factor regarding the stability of Xinjiang's social development. Xinjiang is also a region with a strong sense of stability. One Belt, One Road relies on Xinjiang's scientific research, profound cognition, and effective governance.

(1) Firstly, on this matter is Xinjiang: Chia's Muslim for Northwest:

A summary of the book is the following: "Xinjiang, the nominally autonomous region in China's far northwest, is of increasing international strategic and economic importance. With a population that is mainly non-Chinese and Muslim, there are powerful forces for autonomy, and independence, in Xinjiang. This book provides a comprehensive overview of Xinjiang. It introduces Xinjiang's history, economy, and society, and above all outlines the political and religious opposition by the Uyghur and other Turkic peoples of Xinjiang to Chinese Communist rule." [17]

(2) China and Islam: The Prophet, the Party, and Law:[18]

The following is a review: China and Islam examine the intersection of two critical issues of the contemporary world: Islamic revival and an assertive China, questioning the assumption that Islamic law is incompatible with state law. It finds that both Hui and the Party-State invoke, interpret, and make arguments based on Islamic law, a minjian (unofficial) law in China, to pursue their respective visions of 'the good'. Based on fieldwork in Linxia, 'China's Little Mecca', this study follows Hui clerics, youthful translators on the 'New Silk Road', female educators who reform traditional madrasas, and Party cadres as they reconcile Islamic and socialist laws in the course of the everyday. The first study of Islamic law in China and one of the first ethnographic accounts of law in postsocialist China, China, and Islam unsettles unidimensional perceptions of extremist Islam and authoritarian China through Hui minjian practices of law.

Numerous pertinent papers were published:

Gillette, Maris. "Violence, the state, and a Chinese Muslim Ritual Remembrance" [19]; Lipman, Jonathan N. "White Hats, Oil Cakes, and Common Blood: The Hui in the Contemporary Chinese State" [20]; Ho, Wai-Yip, "Mobilizing the Muslim Minority for China's Development: Hui Muslims, Ethnic Relations, and Sino-Arab Connections." [21].

In the field of politics, the following scholars have produced many research results:

Gladney, Dru C; Grose, Timothy A; Haider, Ziad; Hann, Chris; Harrell, Stevan; Hasmath, Reza; Hernandez, Javier C; Hess, Stephens E; Hyer, Eric; Jacobs, Andrew; Leibold, James; Leung, Beatrice; Rudelson, Justin Jon; Sautman, Barry; Shichor, Yitzhas; Smith Finley, Joanne; Smith, Joanne N; Waite, Edmund; Wong, Edward

\section{Research on Religion, Ethnicity, and Culture}

\subsection{A study on the History}

(1) Kim, Hodong, Holy War in China: The Muslim Rebellion and State in Chinese Central Asia 1864-1877:[22]

The contents of the book are divided into: The Background; Xinjiang in Revolt; The Emergence of Ya'gub Beg's Regime; Muslim State and its Ruling Structure; Formation of New International Relations; Collapse of the Muslim State; Appendix A: Treaty between Russia and Kashghar; Appendix B: Treaty between Britain and Kashghar etc.

(2) Atwill, David G. The Chinese Sultanate: Islam, Ethnicity, and the Panthay Rebellion in Southwest China, 1856-1873: [23]

The contents of the book are divided into: Muslim Yunnanese; Rbellion's Roots: Hanjiansim, Han Newcomers, and Non-Han Violence in Yunnan; Spiraling Violence: The Rise of Anti-Hui Hostilities; "All the Fish in the Pond": The Kunming Massacre and the Rise of the Panthay Rebellion; $\mathrm{Du}$ Wenxiu and the Creation; The Aftermath of Rebellion; and Chinese Characters.

Review: "The Muslim-led Panthay Rebellion was one of five mid-nineteenth-century rebellions to threaten the Chinese imperial court. The Chinese Sultanate begins by contrasting the views of Yunnan held by the imperial center with local and indigenous perspectives, in particular looking at the strong ties the Muslim Yunnan's had with Southeast Asia and Tibet. Traditional interpretations of the rebellion there have emphasized the political threat posed by the Muslim Yunnanese, but no prior study has sought to understand the insurrection in its broader multi-ethnic borderland context. At its core, the book delineates the escalating government support of premeditated massacres of the Hui by Han Chinese and offers the first in-depth 
examination of the seventeen-year long rule of the Dali Sultanate." [24]

(3) James A. Millward, Eurasian Crossroads: A History of Xinjiang:

This book consists of the following: Shrine at Qumartagh south of Khotan; City Walls of Kashgar, 1926; Yaqub Beg; Ferry on the Yarkand River, 1920; British Consulate in Kashgar, c. 1935; Soldiers of the Eastern Turkestan Republic c. 1933-1934; Between China and the Soviet Union, 1910s1940s; Members of a Kazak in their Yurt in the Tianshan; In the People's Republic of China, 1950s-1980s; Livestock Section of the Kashgar Sunday Bazaar; Uyghur and Han Tradesmen; Between China and the World, 1990s-2000s; Vendor of Sheep Lungs and Entrails in Urumchi Former; Balancing Acts; Adil Hoshur Performing on a Tightrope in Xinjiang; and Xinjiang Historical Timeline. [25]

\subsection{Research in Religion, Ethnicity, Culture and Other Fields}

1) The study of Islamic sects and Menhuan

In China, the study of sects and Menhuan plays an important role. After the introduction of Islam into this country, China's Islam has gradually evolved its own unique sectarian system, known as "three major sects" and "four gate officials." The apparent "three major sects" are Gdimu, Ihwani, and Xidaotang. "Four gate officials" or "four Sufi schools" include Hufu ye, Gadlin ye, Zhehren ye, and Kuburen Ye. The research in the field of sects and Menhuan did not continue until after the economic reform and "opening-up." Its research methods and many other aspects had remained limited. From the turn of the $21^{\text {st }}$ century, there have been new changes in the research in this field, not only several new achievements but also a relatively systematic discipline system.

Some papers also explore the study of Sufism, merging with the study of Islam in the world. Because it is believed that Menhuan is a branch of the Sufi order in Northwest China, the difference between Menhuan and sects is not clear. Gedimu is called "Laojiao" and "Zungu sect" in China, which means maintain the tradition of Islam formed after entering China. This differs from the Chinese Muslim community formed after the end of the Ming Dynasty and the beginning of the Qing Dynasty.

2) China's Muslim religious education:

The first proponent of China's Muslim religious education system was $\mathrm{Hu}$ Dengzhou, a Confucian teacher in Shaanxi Province in the Ming Dynasty. He received apprentices at home to whom to teach an advocate-learning classic. From the second disciples, the church moved into the mosque from the private and recruited disciples to teach scriptures in the temple. The practice was called Jingtang education" because of the teaching of classics. The aim was to train teachers and imams for mosques and to teach Muslims religious knowledge. It held a history of more than 400 years from the early development, the late Qing Dynasty and the early Republic of China, around the 1911 Revolution to today. In different periods of development, Jingtang education constantly improved to conform to the trend of the times. However, since the 20th century, it has not received further improvements and developments, especially in the northwest; namely, it undergoes difficulty in being accepted by the mainstream education system because of its medieval status.

In academic research, those inside and outside the church have invariably paid attention to Muslim religious education.

3) A study of the relationship between Islam and Chinese Culture:

In the history of Chinese civilization, as an important part of Chinese traditional culture, religious culture not only played a central role in the spiritual life of believers but also had an impact on the spiritual and cultural life of society. In the 21 st century, under the influence of the upsurge of religious culture in the world, Islamic culture and related fields have also been studied, and many important representative works have appeared.

In terms of publishing papers, since the 1990s, a significant increase in papers related to Islamic culture and related fields has occurred, and novel progress has been achieved in research fields and methods. Both the perspective of world history and culture have been applied to explore the attributes and characteristics of Islamic culture, but many articles have also taken the perspective of specific topics to explore various aspects of Islamic culture.

The representative research results are as follows: Israeli, Raphael. Islam in China: Religion, Ethnicity, Culture, and Politics [26]; Mackerras, Colin. "Some Issues of Ethnic and Religious Identity among China's Islamic Peoples" [27]; AlSudairi, Mohammed Turki A. "Adhering to the Ways of Our Western Brothers: Tracing Saudi Influences on the Development of Hui Salafism in China" [28]; Jorg Friedrichs, "Sino-Muslim Relations: The Han, the Hui, and the Uyghurs" [29].

On of Mackerras, Colin works: "The paper considers the growth of identity among Muslim ethnic groups in China, especially the Sinic people called the Hui. It asks whether this identity springs primarily from ethnicity or religion. While affirming that Islam has grown in influence in China since the 1980s, the paper argues in favor of seeing the balance more strongly in favor of ethnicity. The paper also discusses the impact of the September 11 Incident on Muslims in China. Addressing the issue in terms of ethnicity and religion, it discusses the ramifications of the recognition of the Uyghur based East Turkestan Islamic Movement (ETIM) as a terrorist organization by the US and the United Nations. It explores important issues relating to morality and human rights and concludes that the Chinese have cause to worry about separatist terrorism based on Islamic fundamentalism in southern Xinjiang, but criticizes using recognition of ETIM as a terrorist as a weapon against the general religion of Islam or Uyghur identity." :[27]

And Jorg Friedrichs's works: "Sino-Muslim relations rest upon an informal socio-spatial hierarchy according to which some Muslim groups are more of an asset and others more of a liability. In this informal hierarchy, Hui Muslims are closer to the center than any other Muslim group because 
they are Sinicized, seen as religiously moderate, and mostly live in proximity to non-Muslim Chinese neighbors. Central Asian Muslims, most notably Xinjiang's Uyghurs, are more distant from China's notional center and seen as culturally more alien and prone to religious extremism. The article discusses the historical roots of this socio-spatial hierarchy and systematically examines Sino-Muslim relations in political, economic, and societal terms. It concludes that, despite some problematic features from a western- liberal perspective, the hierarchy continues to enable the Chinese majority to manage a set of otherwise challenging relationships." [29]

This paper is 60 pages long. The author not only studies Hui Muslims in China, but also Turkic Muslims such as Uyghurs. The study is conducted from an interdisciplinary perspective, especially relating to politics, economy, and society. The paper also refers to numerous previous research results. Various papers have also been published in Journal of Muslims Minority Affairs magazine on Islam and Muslims in China:

Fan Ke. "Maritime Muslims and Hui Identity: A South Fujian Case." Journal of Muslims Minority Affairs 21, No. 2 (2001): 309-332.

Fan Ke. "Ups and Downs: Local Muslim History in South China." Journal of Muslim Minority Affairs 23, No. 1 (2003): 63-87.

Chuah, Osman. "Muslims in China: The Social and Economic Situation of the Hui Chinese." Journal of Muslim Minority Affairs 24, No. 1 (2004):

Taynen, Jemmifer. "Interpreters, Arbiters or Outsiders: The Role of the Min Kao Han in Xinjiang Society." Journal of Muslim Minority Affairs 26, No. 1 (2006): 45-62.

Hajji Yusuf Chang, "Institute of Muslim Minority Affairs," Journal of Muslim Minority Affairs, Vol.8, No. 1 (2007): 63-87.

Frankel, James D. "“A politicization': One Facet of Chinese Islam." Journal of Muslim Minority Affairs 28. No.3 (2008): 421-434.

Cooke, Susette. "Surviving State and Society in Northwest China: The Hui Experience in Qinghai Province under the Prc." Journal of Muslim Minority Affairs 28, No. 3 (2008): 401-420.

Frankel, James D. "Chinese-Islamic Connections: An Historical and Contemporary Overview." Journal of Muslim Minority Affairs 36, no. 4 (2016): 569-583.

\section{Conclusion}

To sum up, since the 2000's, the study of Chinese Islam and Muslim in the West has become more and more prosperous. However, none of these works has been translated into Chinese, and there is little understanding of these works in the World research community, which is obviously not conducive to academic exchanges and the further development of Chinese Islamic research. In addition, we should also see that the study of Chinses Islam is still in a relatively marginal position in the western academic circle, which is very weak compared with the developed Chinese study or Islamic world study; The World academic circle should pay attention to and think about these characteristics of the Studies of the Chinses Islam and Muslim, draw lessons from, reflect on and criticize their research methods and achievements, open up the thinking of the study of the Chinses Islam, and promote the study of the Chinses Islam.

\section{Funding}

This work was supported by "Leading Yong Researcher Overseas Visit Program" (Tohoku University, JAPAN), February 1,2020 to January 31,2021 (one year), Research University: University of Oxford (Faculty of Oriental Studies).

\section{References}

[1] Samuel P. Huntington, "The Clash of Civilization and the Remaking of World Order", Simon \& Schuster UK, 2002.

[2] Sachiko Murata, Willam C. Chittick "Chinese Gleams of Sufi Light: Wang Tai-Yu's Great Learning of the Pure and Real and Liu Chih`s Displaying the Concealment of the Real Realm", State Univ of New York Pr, 2000.

[3] Sachiko Murata, Willam C. Chittick, Wei-ming Tu, "The Sage Learning of Liu Zhi: Islamic Thought in Confucian Terms", Harvard University Asia Center, 2009, 678pages.

[4] Seyyed Hossein Nasr, "Foreword", In The Sage Learning of Liu Zhi: Islamic Thought in Confucian Terms, Edited by Sachiko Murata, Willam C. Chittick, Harvard University Asia Center, 2009, pp. V-X.

[5] Tu Weiming, "Epilogue", 581-617, In The Sage Learning of Liu Zhi: Islamic Thought in Confucian Terms, Edited by Sachiko Murata, Willam C. Chittick, Harvard University Asia Center, 2009, pp. 581-617.

[6] Sachiko Murata, "Why Study the Worldview of the Huiru? (1)", Huizu Yanjiu, Vol. 32, 2012, pp. 9-10.) and Willam C. Chittick, "Why Study the Worldview of the Huiru? (2)", Huizu Yanjiu, Vol. 32, 2012, pp. 11-12.

[7] Zvi Ben-Dor Benito, The Dao of Muhammad: A Cultural History of Muslims in Late Imperial China. Cambridge, MA: Harvard University Asia Center, 2005.

[8] James D. Frankel, Rectifying God's Name: Liu Zhi's Confucian Translation of Monotheism and Islamic Law. Honolulu: University of Hawaii Press, 2011.

[9] Islamic Thought in China: Sino-Muslim Intellectual Evolution from the $17^{\text {th }}$ to $21^{\text {st }}$ Century. Edited by Jonathan Lipman. Edinburgh: Edinburgh University Press, 2016.

[10] Tontoni, Roberta. Muslim Sanzijing: Shifts and Continuities in the Definition of Islam in China. Leiden: Brill, 2016.

[11] Maris Boyd Gillette, Between Mecca and Beijing: Modernization and Consumption Among Urban Chinese Muslims, Stanford: Stanford University Press, 2000.

[12] Li Zhang, Book Reviews-- Between Mecca and Beijing: Modernization and Consumption Among Urban Chinese Muslims--, Journal of Political Ecology, Vol. 9, pp. 3-4, 2002. 
[13] Reference: Jiang Jianing, "An anthropological return visit to Niujie (Oxen Street) hui Community", Master thesis, Minzu University, 2011--17pags.)

[14] Maria Jaschok, shuijingjun, The History of Women's Mosques in Chinese Islam: A Mosque of Their Own, London: Curzon Press, 2000

[15] Xinjiang: China's Muslim Borderland, edited by S. Frederick Starr, Armonk, NY: M. E. Sharpe, 2004.

[16] Lisabeth Alls, Musumans de Chine: Une Anthropologie des Hui du Henan, Paris: EHESS, 2000.

[17] Michael Dillon, Xinjiang: Chia's Muslim for Northwest, London: Routledge, 2004.

[18] Erie, Matthew S. China, and Islam: The Prophet, the Party, and Law. New York: Cambridge University Press, 2016).

[19] Gillette, Maris. "Violence, the state, and a Chinese Muslim Ritual Remembrance" Journal of Asian Studies, Vol. 67, No. 3 (2008): 1011-1037.

[20] Lipman, Jonathan N. "White Hats, Oil Cakes, and Common Blood: The Hui in the Contemporary Chinese State." in Governing China's Multiethnic Frontiers, edited by Morris Rossabi, 19-52. Seattle: University of Washington Press, 2004, 19-52.

[21] Ho, Wai-Yip, Mobilizing the Muslim Minority for China's Development: Hui Muslims, Ethnic Relations, and Sino-Arab Connections." Journal of Comparative Asian Development, Vol. 12, No. 1, 84-112, 2013.

[22] Kim, Hodong, Holy War in China: The Muslim Rebellion and State in Chinese Central Asia 1864-1877. Stanford, CA: Stanford University Press, 2004.

[23] Atwill, David G. The Chinese Sultanate: Islam, Ethnicity, and the Panthay Rebellion in Southwest China, 1856-1873. Stanford, CA: Stanford University Press, 2005.
[24] (https://books.google.co.uk/books/about/The Chinese Sultana te.html?id=Da2M_viEclEC\&redir_esc=y)

[25] James A. Millward, Eurasian Crossroads: A History of Xinjiang. London: Hurst, 2007.

[26] Israeli, Raphael. Islam in China: Religion, Ethnicity, Culture, and Politics. Landan, MD: Lexington Books, 2002.

[27] Mackerras, Colin. "Some Issues of Ethnic and Religious Identity among China's Islamic Peoples." Asian Ethnicity, Vol. 6, No. 1, 3-18, 2005.

[28] Al-Sudairi, Mohammed Turki A. "Adhering to the Ways of Our Western Brothers: Tracing Saudi Influences on the Development of Hui Salafism in China.” Sociology of Islam, Vol. 4, no. 1, 27-58, 2016.

[29] Jorg Friedrichs, "Sino-Muslim Relations: The Han, the Hui, and the Uyghurs", Journal of Muslim Minority Affairs, Vol. 37, 2017.

\section{Biography}

Alimu Tuoehti, Assistant Professor at Tohoku University, JAPAN; Academic Visiting Scholar at Oxford University (The Oriental Institute), UK. His research fields: History of thought, Religious studies, Theory of comparative culture, Area studies, Philosophy, Islamic studies, Japanese Intellectual History, Chinese philosophy. Research subject's: "A theoretical study about the uniqueness of the marginal culture and cultural change: On the relationship between East Asia and the Islamic civilization zone and its interdisciplinary research", etc. His focus studies in cultures of China, Japan and Central Asian Islamic Countries included Turkey, the relations among different cultures and thoughts. Dialogues among various civilizations. 